\title{
The Economics of Decline in the Media Industry: Survival Strategies of American Print Media Firms and Implications for a Diminishing Print Media Industry in Nigeria*
}

\author{
EKEANYANWU, Nnamdi Tobechukwu, BATTA, Herbert, OYOKUNYI, Jon Ita \\ University of Uyo, Akwa Ibom State, Nigeria
}

\begin{abstract}
The media industry plays a central role in the emergence of a politically, socially, and economically conscious citizenry. This role has elevated the industry as a major stakeholder in the political, socio-cultural, and economic development of the people. This essential role, however, has come under serious threat following the emergence of the Digital Age, changing social trends, and a global economy that is in distress. This is the main reason this paper investigates the survival strategies adopted by the US print media industry to deal with the decline and see how the Nigerian print media industry that is facing similar decline can benefit from the strategies. The method of study is qualitative. We gathered data through in-depth interviews and on-site observation of the operations of the selected media organizations. We also reviewed literature provided by the media firms and the ones that are already in the public domain. Our findings confirm recent projections that the American and Nigerian media industries are truly facing economics of decline and that the Nigerian industry is worst hit. The study identified some of the strategies adopted by the American print media industry to deal with the economic recession to include introduction of online editions, use of pay wall, free online views, Search Engine Optimization, Micro-funding, etc. After thorough interrogation of the literature and results, we conclude that the Nigerian print media industry could apply similar strategies used in the US to address its own negative economic situation. We also recommend an upgrade in the media training curricula to address some of these concerns effectively leading to the emergence of "Media Entrepreneurship" as a course in Communication/Media Departments in Nigerian universities.
\end{abstract}

Keywords: economics, decline, survival strategies, Print Media Industry, Nigeria, America

\section{Introduction}

It is no longer debatable that the media industry anywhere in the world is a major nerve centre coordinating other sectors or industries and serving as a major link between one industry and others, especially between the government and the governed. The industry plays a central role in the emergence of a politically, socially, and economically conscious citizenry. This role has elevated the industry as a major stakeholder in the political, socio-cultural, and economic development of people. This also explains why the media are often

\footnotetext{
* Acknowledgement: This study was conducted with a Grant from the Tertiary Education Trust Fund (TETFUND), Nigeria 2011-2014 TETFUND Research Project Intervention for the University of Uyo and released in 2016. However, the effective Award date is February 01, 2017 to February 01, 2018.

EKEANYANWU, Nnamdi Tobechukwu, Ph.D., Department of Communication Arts, University of Uyo.

BATTA, Herbert, Ph.D., Department of Communication Arts, University of Uyo.

OYOKUNYI, Jon Ita, Department of Communication Arts, University of Uyo.
} 
regarded as the "Fourth Estate of the Realm", "Watchdog of the Society", and other similar recognitions that place the media at the heart of nation building. This essential role of the media, however, has come under serious threat following the emergence of the Digital Age, changing social trends, and a global economy that is in distress. This, we refer to in this paper as economics of decline.

Since the beginning of this Century, the economics of decline has hit the print media industry in the US. How has the US media managed this economic crisis? What strategies and alternative journalism models have the US print media industry evolved to deal with the economic crisis? Are there implications of the US experience in dealing with the crisis for a declining print media industry in Nigeria? In other words, can the Nigerian print media industry facing similar decline benefit from the practical strategies applied in the US case? These posers form the basis for this study.

The traditional print media in the US are shrinking. According to Kurpius, Metzgar, and Rowley (2010, p. 359), "what started as the gradual decline typical of a mature industry has snowballed with the ongoing economic crisis. The recession is the culprit for more than 30,000 newsroom employees who lost their jobs through layoffs, buyouts, firings, and newspaper closings between June 1, 2007 and September 30, 2009". The Project for Excellence in Journalism (PEJ) did extensive studies in this area and corroborates Kurpius, Metzgar and Rowley above. In its 2009 State of the News Media report, PEJ predicted that more cuts are expected in the media industry and that one in five newspaper journalists would lose their jobs in the coming decade. According to the same PEJ (2009) report, newspaper advertising revenues also dropped to $23 \%$ between 2007 and 2009 to complicate the industry's headaches. Till date, the trend has not changed as ad revenues continue to drop. The same scenario in the print media was also applicable in the broadcast media where revenues for local television channels dropped seven percent in 2008, while audience growth remains flat or declining (PEJ, 2009). A similar study by PEJ (2008) found that journalists were now more occupied by the financial problems of the industry than other primary concerns of journalism; an indication of a depressed industry.

Curran (2010, p. 465) provides further facts to back up the economic recession in the print media industry thus: "the migration of advertising to the web, compounded by the 2008-9 recession, has led to a rising number of newspaper closures, and also contradictions in news operations, giving rise to increasing alarm". Continuing, Curran notes that between January 2008 and September 2009, 106 local newspapers closed down in Britain while in America, major newspapers like Christian Science Monitor and Seattle Post ceased print publication. The rise of the Internet also had enormous contribution to the situation as it led to the "hemorrhaging of paid jobs in journalism" (Curran, 2010, p. 465). These of course are enough reasons to worry Western journalists to shift their focus from the primary concern of journalism to their financial sustainability. And in Nigeria, the commercialization of news has become inevitable for the same reason of financial sustainability.

Kaye and Quinn (2010) further corroborate the PEJ findings thus:

The value of news media companies around the world has crashed since the global financial crisis started to bite in 2008. In America alone, newspapers lost $\$ 64.5$ billion in market value that year. Traditional news organizations are struggling to survive. But the economic downtown has only speeded up a process that has been underway for decades. Emerging technologies and changing social trends began to disrupt established media business models and practices long before the latest crisis on Wall Street. (p. 1)

The "full horror" of the global decline, according to Kaye and Quinn (2010), manifested with the crippling of mainstream media's source of revenue, advertising. This, according to Kaye and Quinn (2010) led to: 
...decline of print newspapers and magazines, and decisions to produce online-only editions or outsource content. In the US, advertising revenue plummeted between 2007 and 2008... In 2008, American newspaper advertising revenue dropped 16.4 percent to $\$ 37.9$ billion. And eMarketer estimated another $\$ 10$ billion of advertising income would disappear by 2012 , leaving the industry half of the size it was in 2005 .

Job cuts followed the decline in revenue and market valuation. In 2000, there were about 56,400 newsroom workers in the US. But that number fell by more than 15,000 between 2006 and early 2009 because of layoffs. (p. 7)

Our concern for the print media industry is based on the understanding that "newspapers are major employers of journalists and traditionally the largest injectors of news stories into the news cycle" (Young, 2010, p. 610). Continuing, Young (2010) argues that the newspaper industry in the US and UK are ailing. Her arguments are supported by a 2008 report of the World Association of Newspapers (WAN, 2008) that predicted that decline will hit the newspapers most. Emily Bell of The Guardian, cited in the Media Entertainment and Arts Alliance (MEAA, 2008, p. 4) argues, "We are on the brink of two years' carnage for Western media... of systematic collapse, not just a cyclical downtown". In a similar observation, the Financial Times of December 10, 2008 carried a report from Deloitte that, "the newspaper and magazine industry could be decimated in 2009" (Young, 2010, p. 610). Meyer (2004) earlier predicted that newspapers would run out of readers in 2043 and a 2006 edition of The Economist claimed that, "half the world's newspapers [were] likely to close in the foreseeable future".

These closures and redundancies, according to Curran (2010), are undermining quality journalism. Citing Dear (2009), Curran observes, "Local and national democracy is suffering" and "Councils, courts and public bodies are no longer being scrutinized".

With a solution mentality however, H. Batta, Ekeanyanwu, and N. W. Batta (2017) citing Lavrusik (2009) note that:

Newspapers are struggling in terms of finances and that the underpinning issues are business-driven, structural, cultural, and related to the industrialized basis of circulating newspapers. ... newspapers should do 12 things to survive: putting the web first and reporting from multiple platforms, going niche, offering unique content in print, becoming curators and contextualizers, integrating real time reporting, and restructuring internal cultures. Others include encouraging innovation, investing in mobile technologies, communicating with readers, building communities, and reconsidering the use of pay walls for high-end content. (H. Batta, Ekeanyanwu, \& N. W. Batta, 2017, p. 291 citing Lavrusik, 2009)

In the European setting, Collins (2013, p. 1) observes that, "a long illness usually precedes the death of a paper; journalists are sacked, newsgathering budgets are cut, pagination is reduced, and potential consumers are excluded by price rises". He states that, The Guardian media group lost $£ 129 \mathrm{~m}$ in 2012 and that two UK papers - The London-based Evening Standard and The Independent have indicated that they needed investors to take up part of the newspapers' liabilities.

All of these are indicative of a global economy in recession which has obviously manifested in a global journalism crisis and decline. However, one may ask why the peculiar attention to the American print media industry? The answer is simple: One major export of the US to the developing world is its media system/structure, which supports societal freedom and a democratic culture. Therefore, most nations that have embraced American type democracy have also embraced American type media system. Nigeria is one developing nation that embraced both American type democracy and media system (Ekeanyanwu, 2013). The implication of this is that the decline in the US print media industry has started manifesting in very dangerous dimensions in the Nigerian print media industry because of the similarities in ownership, structure, and general operations of the two industries. 
The following statistics help argue this thesis that the decline in the US is also manifesting in Nigeria. In 1980, the circulation strength of ten leading newspapers in Nigeria was 631,000 (Ugboajah, 1980) while by 1995, the figure rose to 1,065,000 (Maja-Pearce, 1995). However, by 2009, the decline set in. A study commissioned by three media-related associations: Advertising Association of Nigeria (ADVAN), Media Independent Practitioners Association of Nigeria (MIPAN), and Association of Advertising Agencies of Nigeria (AAAN) in 2009 shows that the "top seven newspapers in the country - Punch, The Nation, The Sun, Vanguard, Guardian, This Day, Daily Trust, Tribune, Champion, and Compass - have a combined daily sales of 176,202 copies" (Brandwork Nigeria, 2009). This is not all. All the newspapers covered in the study reported above, have combined circulation strength of 300,000 copies per day. This is happening in a country with population strength of over 170,000,000 people and literacy level above 40 percent.

Beyond these statistics, a careful observer of happenings in the print media industry in Nigeria will note the declining circulation strength and sales, loss of revenue and impact, and closures caused by inability to break even. In a recent study, Ukonu, Ani, and Ndubisi (2013) found that the Nigerian print media industry has suffered a major setback with the emergence of digital forms of news dissemination. In other words, they observe that the Internet and social media for instance, have eaten deep into the market share of the Nigerian print media industry. These become very worrisome especially in Nigeria where newspapers play significant roles in the socio-political development of the nation (Ekeanyanwu, 2013).

The current authors, as part of the execution of a Grant received from the Tertiary Educational Trust Fund (TETFUND) sponsored study, recently established the fact that the Nigerian print media industry is still in economic recession or decline. The authors studied four mainstream and national-based newspapers in Nigeria (Guardian; The Sun, Daily Trust and Leadership) to reach their conclusions. The findings of the study are published in H. Batta, Ekeanyanwu, and N. W. Batta (2017) and Oyokunyi, Ekeanyanwu, and Aniebo (2017). These studies therefore serve as the background to the current effort to study the US print media industry and identify potential or possible strategies that could help the Nigerian print media industry come out of the woods even if the industry players are yet to appreciate the long-term implications of a reclining industry.

Why is the US print media industry the specific industry to investigate for possible clues to rescue the Nigerian print media industry? First and as earlier stated, the Nigerian press shares common history with the US media system because the latter influenced the discipline and practice of the profession in Nigeria. The Western type media system has been the dominant media system in Nigeria before and after the country's political independence.

Second, the early indigenous scholars in the discipline who shaped media education and practice in Nigeria where mostly trained in the US or Western type universities. When they returned to Nigeria, they helped shape media education and practice and the footprints are still visible decades after.

Third and most importantly, since the emergence of the decline in the US media, efforts have been made to address the situation. This led to some new ways to support the traditional media firms. Some of these include Aggregation, Search Engine Optimization, Hyperlocal media, Dayparting strategies and sponsorship models. Other strategies adopted include Microfunding and Micropayments, Collaboration between mainstream media and citizen journalists, narrowing a media focus with Niche and Passion content, and Partnerships.

Based on these, it is obvious that the US print industry is addressing its own decline. However, the literature on how these strategies are being implemented and the various levels of success remain scanty. This is the main reason the current authors choose to investigate some of the conventional print media firms in the 
US to identify the strategies adopted to deal with the decline and the levels of success achieved. It is also the ultimate aim of this paper to seek ways to domesticate these strategies within the Nigerian print media industry to address similar economics of the decline in the Nigerian media industry.

\section{An Overview of the Three US-Based Print Media Firms}

The New York Times was founded as the New-York Daily Times on September 18, 1851 and published by Raymond, Jones, and Company (The New York Times Company, 2017). The newspapers running vision is captured thus:

We shall be Conservative, in all cases where we think Conservatism is essential to the public good;- - and we shall be Radical in everything which may seem to us to require radical treatment and radical reform. We do not believe that everything in society is either exactly right or exactly wrong; - what is good we desire to preserve and improve; - what is evil, to exterminate, or reform. (The New York Times Company, 2017)

In 1857, the newspaper shortened its name to The New-York Times and by 1890; it dropped the hyphen in the name. The New York Times is an award winning media firm in the United States having won up to 122 Pulitzer Prizes, more than any other newspaper in the US (The New York Times Company, 2017).

The second news media firm studied is The Los Angeles Times "which was first published on December 4, 1881, as the Los Angeles Daily Times under the direction of Nathan Cole Jr. and Thomas Gardiner" (The Los Angeles Times, 2017). A historical account in The Los Angeles Times (2017) notes thus:

The Los Angeles Times was first printed at the Mirror printing plant, owned by Jesse Yarnell and T.J. Caystile. Unable to pay the printing bill, Cole and Gardiner turned the paper over to the Mirror Company. In the meantime, S.J. Mathes had joined the firm, and it was at his insistence that the Times continued publication. In July 1882, Harrison Gray Otis moved from Santa Barbara to become the paper's editor. Otis made the Times a financial success. In an era where newspapers were driven by party politics, the Times was directed at Republican readers. (p. 3)

The third news media firm studied is the Chicago Tribune, which was founded in 1847 as a daily newspaper based in Chicago, United States of America. It is owned by Tronc, Inc., formerly Tribune Publishing (Wendt, 1979). It is the "eighth-largest newspaper in the United States by circulation [and became the second-largest under Tribune's ownership after the Chicago Tribune's parent company purchased the Los Angeles Times]" (Wendt, 1979).

These three US-based newspapers were selected because they are among the leading newspaper firms in the United States that have visible strategies to address the decline in the industry. The extant literature on how these newspaper firms are dealing with the decline in their individual firms are also available in the public domain. The business executives of these firms also agreed to participate in this study to further substantiate some of the findings gathered as part of literature review.

\section{Problem Statement}

The print media industry all over the world relies heavily on advertising revenues first and readership network to sustain its operations. The 21 st Century reality is that print news organizations are losing advertising revenues and their audiences because of the digitalization that emerged in the beginning of the Century. Meanwhile, the new online news providers that are "stealing" traditional print media audiences and advertising revenues are unable to develop business models to support comprehensive and quality news coverage and distribution. 
The questions arise: How will quality journalism be funded and sustained in the long term? Will traditional print media firms remain viable in terms of meeting their obligations as business entities? The current digital platforms that helped fast track the decline, how far will they go and how long will they last? The other alternative methods of newsgathering and dissemination developed in the US, how will they be funded in the long run?

In reality, the US print media industry is already addressing these questions but the outcome, success or failure rates, models of implementation, etc. remain scanty in the literature. However, the effort and strategies being applied in the US print media industry to address its present decline are worth our scholarly attention especially for a Nigerian print media industry that appears to be also grappling with a similar economic situation. This central problem informs this investigation and the selection of the US as the research location and Nigeria as a potential beneficiary of the findings of this investigation.

\section{Objectives of the Study}

The main objective of this study is to investigate the survival strategies adopted by the US print media industry to deal with the decline in the industry and to see how the Nigerian print media industry that is facing similar decline can benefit from the strategies. In specific terms, this paper aims to achieve the following:

(1) Identify and explain the indices of decline in the US and Nigerian print media industries.

(2) Identify the survival strategies or alternative newsgathering and dissemination models adopted by the US print media industry to deal with the decline in the news industry.

(3) Determine the implications of the identified survival strategies on the Nigerian print media industry that is facing similar decline.

\section{Research Questions}

(1) What are the indices of decline in the US and the Nigerian print media industries?

(2) What are the survival strategies or alternative newsgathering and dissemination models that have evolved to address the decline in the US print media industry?

(3) What are the implications of the identified survival strategies on the Nigerian print media industry that is facing similar decline?

\section{Significance}

This project is important to the US and Nigerian print media industries in many ways. First, the study serves as an external assessment of the operations and strategies evolved by the US media industry to address the economic recession. The review helps evaluate the US operations and performance.

Second, this is a sort of social responsibility project. If the identified strategies are effectively mobilized in the Nigerian media industry, the US will of course take the credit having evolved the strategies, supported this study and offered technical assistance in adapting the strategies in Nigeria.

For Nigeria, we have observed that the Nigerian media training institutions appear busy training students for a fast disappearing industry. No serious attempt has been made since the economic recession in the media industry set in to address the situation theoretically through a comprehensive review of the curricula used for training media professionals in Nigerian higher institutions of learning. This study may therefore refocus the 
training curricula in Nigeria to begin to address this decline. We therefore expect that the curriculum reviews will lead to the emergence of "Media Entrepreneurship" as a course in Communication/Media Departments in Nigerian universities. Such a course does not exist for now.

Fourth, some elements in the Nigerian print media industry are still in a state of denial over its declining fortunes. This study may offer the industry reasons to come out of that situation and face reality. In essence, the Nigerian newspaper industry will be offered solutions and models it can adopt to remain in competitive media business.

\section{Method}

This study is largely based on the qualitative paradigm. Therefore, we made use of in-depth interview as the major instrument of data gathering. Qualitative research is preferred when the intention is to determine and theorize about significant issues that largely affect a human population or concern a social phenomenon (Jamshed, 2014). Gill, Stewart, Treasure, and Chadwick (2008, p. 292) further support the use of this method of research when they argue that qualitative methods, such as interviews, "provide a deeper understanding of social phenomena than would be obtained from purely quantitative methods such as questionnaire".

We gathered data through in-depth interviews of two Business Executives of the selected newspaper firms and on-site observation of the operations of the firms. We also reviewed literature provided by the media firms under investigation and the ones that are already in the public domain. We selected The New York Times, The Los Angeles Times, and the Chicago Tribune because they have evolved different strategies to deal with the recession in the industry. They were also selected because of their circulation strength, reach and sustainability models that were appealing to the current researchers.

With the help of three Research Assistants (RAs) that were engaged and trained on arrival of the Lead Author in the United States, interviews were organized and conducted with the two Business Executives, contributors, and community members of the selected media firms, most of who elicited confidentiality clauses from us before agreeing to speak. Additional interviews were carried out as the data gathering process intensified. We also conducted online search on platforms such as Guidestar.com and the websites of the firms to get some vital information about the firms. The team also reviewed documents published by the selected media firms as part of the data gathering technique.

We applied the grounded theory as a framework for our analysis, "following the lead of Geertz (1973) and his use of "thick descriptions"” as applied by Kurpius, Metzgar, and Rowley (2010, p. 363) in their study on sustaining Hyperlocal media. The interview protocols were standardized but with a lot of flexibility to follow up on issues that emerged in the key interviews. Adopting Kurpius et al. methodology, "one protocol was developed for people within the organization and another for community members and citizen contributors, but both followed similar lines of questioning. This format allowed conversations to progress naturally, with an emphasis on obtaining a person's point of view" (Kurpius et al., 2010, p. 363).

All the interviews lasted for about 45 minutes and were recorded and later transcribed. Supplementary notes were also taken by the lead researcher and the RAs to forestall any recording failures. The results are presented as part of literature, noting that the fundamental issues that the study sought to unravel, using the Research Questions as guide, were mostly obtained from extensive search and review of literature. The interviews merely confirmed what we already gathered in literature and published documents about the state of the newspapers and what they have done and are doing to address the decline. We also found out that the 
business information the firms did not want to talk about were also not on any public domain, thus, signposting the literature review as the main source of data that have been presented and discussed here.

\section{Results and Discussion}

This section on results and discussion is based on the Research Questions that guided the data gathering process. Since this study is largely qualitative, the data presentation, analysis and discussion of findings are merged to bring out any theoretical underpinnings and highlight major concerns with specific focus on the objectives of the study.

\section{Summary of Responses to Research Question One}

\section{What Are the Indices of Decline in the US and the Nigerian Print Media Industries?}

The decline in the American print media industry is real because of dwindling advertising revenues and free readers who continue to crave for quality journalism without plans to pay for it. As we have already observed, quality journalism is expensive to produce and consumers have started scouting for alternatives rather than staying committed to the traditional newspaper.

The survival of American newspapers in the second half of the 20th Century was largely tied to advertising revenue. According to Professor Robert Picard of Jonkoping International Business School in Sweden, who is reputed to be one of the world's most eminent media economist,

Advertising sales accounted for $71 \%$ of newspaper income in 1956 compared with $82 \%$ by 2000 . The category proportion of advertising also changed. By 1950, retail advertising made up 57 percent of advertising revenue, national advertising 25 percent and classified advertising 18 percent. Half a century later, retail and classified were nearly equal in terms of their contribution (44 percent and 40 percent respectively) and national advertising provided only 16 percent of total advertising revenue. These shifts made newspaper more dependent on classified employment, automobile, and real estate advertising that tend to be more cyclical and respond more to changes in the economy than brand advertising that makes up the bulk of television advertising. (Cited in Kaye \& Quinn, 2010, p. 6)

Professor Picard (as cited in Kaye \& Quinn, 2010, p. 6) further argues that, "the newspaper industry was dependent upon advertising for the bulk of its income across the five decades but that dependence grew stronger during the final quarter of the century". This argument is further supported by the Project for Excellence in Journalism in its 2009 State of the News Media Report thus:

Newspapers have often used the cover price as a tool to manipulate circulation figures and advertising rates. So, they have always been reluctant to raise the cover price for fear of losing readers and having to charge lower ad rates. Circulation at US newspapers peaked at 63.3 million in 1984. By the end of 2008, US weekday newspaper circulation had dropped to a combined 48.6 million. The declines in the print newspaper circulation, which had begun to accelerate alarmingly in the late 2003, only became deeper in 2008. (PEJ, 2009)

The global financial crisis of 2007-2008 also had enormous negative impact on the American print media industry. The greatest impact of this crisis was the crippling of the mainstream media's primary source of income, advertising, and reduced the options media companies had for borrowing money to expand (Kaye \& Quinn, 2010). This loss of income facilitated many negative events in the media industry in the US and forced in changes that many companies may have anticipated but never expected to happen so fast. Some of these changes included decline of the traditional print newspaper, and the decision to produce online-only issues or outsourcing of content generally. Kaye and Quinn (2010, p. 7) capture this situation better thus: 
In the US, advertising revenue plummeted between 2007 and 2009, marking the first three-year decline since the Great Depression of the 1930s. In 2008, American newspaper advertising revenue dropped 16.4 percent to $\$ 37.9$ billion. And eMarketer estimated another $\$ 10$ billion of advertising income would disappear by 2012 , leaving the industry half the size it was in 2005 .

To further explain the US situation, Saperstein (2014) observes that US newspapers are struggling to survive in the age of technology. Noting that, "in 2013, total revenue within the newspaper industry decreased by 2.6 percent representing over a billion dollars in lost funds. As a result, The New York Times, The Wall Street Journal and USA Today have all experienced major losses, with each of the papers cutting anywhere from 20 to 100 newsroom jobs..." He adds that, "from 2006 to 2012, the number of working journalists in the United States decreased by 17,000" (Saperstein, 2014, p. 2). To survive in the age of technology, Saperstein suggests that, "innovation in the news industry will involve changing not only the traditional journalism model, but also incorporating changes into its business technological and marketing sectors as well" (p. 4).

Providing more details of the decline of the newspaper industry in the West, United States inclusive, Barthelemy et al. (2011) note:

\footnotetext{
Markets where print newspapers are more dependent on revenues from advertising were more severely affected by the economic recession. Worldwide, advertising comprises 57 percent of overall newspaper revenue while circulation makes up 43 percent. In the US, newspapers generate on the average 73 percent of revenues from advertising, and sell their print copies at lower prices. In Germany, newspapers generate 53 percent of their revenues from advertising. In the United Kingdom the average is 50 percent. From 2008 to 2009, newspapers' ad revenues declined 25 percent in the US, 22.1 percent in the UK and 2.2 percent in Brazil. By contrast, they increased by 10 percent in Egypt and Lebanon and by more than 13 percent in India. Newspaper circulation fell by 10.6 percent in the US, 5.6 percent in Europe and 4.6 percent in South America; and grew by 1 percent in Asia and 4.8 percent in Africa from 2008 to 2009. (p. 36)
}

Professor Jay Hamilton of Duke University, another notable media economist, was quoted by Kaye and Quinn (2010) of having observed that by the start of 2008, the market valuation of America's publicly traded newspaper firms had dropped to $\$ 23$ billion relative to the end of 2004 . This amounted to a devaluation of about 42 percent. During the same period, non-newspaper Internet firms enjoyed $43.7 \%$ of local online ads while print newspapers only managed 33.4 percent. The immediate effect of these declines was the loss of print media jobs in America. For instance, in 2000, there were about 56,400 newsroom workers in the US but between 2006 and 2009; only 41,400 of such jobs were left because of layoffs (Kaye \& Quinn, 2010).

These declines have continued unabated till date leading to an industry that is now a shadow of its former self. More newsroom jobs have been lost from 2009 to 2017 and the ad revenue during this period has also continued to drop. This was what prompted Emily Bell, who is the Director of Digital Content for British Content, The Guardian, to note thus: "this is systematic collapse, not just a cyclical downturn. Even the surviving brands will have to go through a period of unprofitability".

The same situation is applicable in the Nigerian print media industry as Oyokunyi, Ekeanyanwu, and Aniebo (2017) noted and further corroborated by another related study by H. Batta, Ekeanyanwu, and N. W. Batta (2017). The two related studies used four mainstream Nigerian newspapers to conclude that the Nigerian newspapers are suffering from decline and that this may continue beyond 2020 unless something positively dramatic happens to change the fortunes of the print media industry in Nigeria. For example, Oyokunyi et al. (2017) who studied three of the four newspapers on the specifics of their economic challenges found out from The Sun that: 
... since the country has no functional plant that manufactures newsprint, the challenges of forex/high exchange rate has become a torn in the flesh of the print media in Nigeria, as this has increased cost per ton. The second specific challenge from the perspective of The Sun newspaper is that most print media today, including The Sun, are struggling to pay staff salaries and allowances as at when due because of dwindling ad revenues and low circulation figures. The Sun also suggested that even when the firm receives too much or certain kinds of ad, that this affects space for editorial content and the consequence of a preference given to advertising space over editorial content is that many stories that are of interest to the reading public are not given adequate coverage. This could eventually result in many readers switching to other forms of media for their daily news needs. The Sun also suggested that the high inflation in the country has dramatically increased both its recurrent and capital expenditures to unmanageable proportions. (p. 318)

Continuing, Oyokunyi et al. (2017) also found out the Guardian and the Leadership newspapers share similar economic circumstances thus:

The Guardian, on its part emphasizes that the specific economic challenges centre more on finance, occasioned by the biting economic situation in the country. According to the newspaper, because of the unfriendly business environment, there have been high incidences of drop in readership, low sales, and dwindling ad placements from individuals, governments and organizations. The challenges of funding therefore affect many traditional areas of engagements by the organization. These include training, staff motivation, and engagement of experts in relevant fields. Lack of these eventually leads to gradual decline in quality of publications.

The Leadership concurs with what The Sun said about the harsh economic climate affecting its business activities and admits that the firm has been affected by economic recession, rise of the online/new media, and dwindling advertising revenue. These, according to the newspaper, have resulted in the inability of organization to pay workers salaries as at when due. (p. 319)

In a similar vein, Batta et al. (2017) who studied the Daily Trust newspaper to find its specific economic challenges note these about the newspaper:

For Daily Trust, readership has not suffered greatly. In 2008 for instance, Daily Trust Sunday circulated about 10,000 copies but in 2016, its circulation had risen to 40,000 copies. Today in 2017, Daily Trust circulates between 35,000 and 40,000. It could do much more than this if potentials are maximized. A major setback for Daily Trust has been the insurgency in the North East. Insecurity in that part of the North which is really the main base of the paper has killed economic activities in the region and hampered the capacity of people to buy/read newspapers.

...The most crushing challenge is the hike in the cost of printing materials: ink, newsprint, spare parts, and engineering experts who are often sourced from abroad. The difficulty in accessing foreign exchange for these needs is telling. Daily Trust has been compelled to increase its cover price from $\$ 150$ to $\$ 200$, but newsstand sales or cover price of newspapers never covers any cost. In other words, sales of the newspaper copies are usually inadequate to sustain running or production costs. Another major issue is that ad revenues are never enough. (p. 302)

These two studies served as background to the current effort and inform the conviction of the present authors to investigate the American print industry that has undergone similar decline and by so doing, find clues that could help address similar economic situations in the Nigerian print media industry.

\section{Analysis of the Responses on Research Questions Two and Three}

\section{Survival Strategies Adopted by American Print Media Industries and Implications for Nigerian Print Media Industry Undergoing Similar Decline}

The major highpoint of this study is to identify the survival strategies employed by the American print media industry to address its decline and critically analyze how the Nigerian print media industry that is undergoing similar economic challenges at present could leverage the strategies and get the industry out of the economic recession. 
It is also important to point out that some of the strategies are still debatable today as some industry experts continue to argue that they are wrong while some think such were right moves to stabilize a failing industry. In November 2003, the then President of the Tribune Company, Jack Fuller, argued that the most stupid thing the American newspaper industry did was to give away content on the web for free. This argument is supported by the "Free" author, Anderson (2009) cited in Kaye and Quinn (2010, p. 10), who argues,

We have built a country-size economy online where the default price is zero - nothing, nada, zip. Digital goods from music and video to Wikipedia - can be produced and distributed at virtually no marginal cost, and so, by the laws of economics, price has gone the same way, to $\$ 0.00$. For the Google Generation, the Internet is the land of the free.

In their own interrogation of the above argument by Anderson (2009), Kaye and Quinn (2010) state that, "the global financial crisis may be helping to spread the 'Free' business model because when the economy is in recession people look for free options". This again justifies Anderson's view that when people do not have money, $\$ 0.00$ becomes a very good price. Anderson concludes his argument when he predicted, "an accelerating shift to free open source software and free web-based productivity tools such that Google does. The web has become the biggest store in history and everything is 100 percent off" (cited in Kaye \& Quinn, 2010).

Jack Shafer, the Slate editor-at-large, however, argues that newspaper consumers are not entirely against paying for content. He cites the following examples to buttress his points:

The Wall Street Journal and the Financial Times offer a hybrid model of some free content combined with a pay wall for other types of information. Both The New York Times and The Times in the UK are able to charge for their famous and addictive crossword puzzles. The Sun newspaper in the UK charges users for sending text messages to them, at 25p per text, with updated information about general news, celebrity gossip, and sports news. Users can also subscribe to receive texts about their favorite soccer teams. The Sun also offers texts with betting tips on horse racing.

Having established what this section hopes to achieve, we now analysis our findings of what the selected US-based newspapers did to stay afloat in the midst of decline and conclude with what we think the Nigerian newspapers still battling economic recession could learn and do to stay afloat as their US counterparts.

Our general observation of the subject, interview with employees and customers of the firms, and review of literature as well as other relevant documents, especially the book by Kaye and Quinn (2010) on, Funding Journalism in the Digital Age: Business Models, Strategies, Issues and Trends and the most recent publication by Usher (2017) on, Making News at The New York Times, provided certain strategies that were commonly applied by the print media firms to address the decline that set to destroy the industry.

First of the newspapers is The New York Times (NYT). The New York Times began publishing daily on the World Wide Web on January 22, 1996, "offering readers around the world immediate access to most of the daily newspaper's contents". Since its online launch, information from the website and later corroborated by the Business Executive during the interview shows that:

The newspaper has consistently been ranked one of the top websites. Accessing some articles requires registration, though this could be bypassed in some cases through Times RSS feeds. The website had 555 million page views in March 2005. The domain nytimes.com attracted at least 146 million visitors annually by 2008 according to a Compete.com study. The New York Times website ranks 59th by number of unique visitors, with over 20 million unique visitors in March 2009 making it the most visited newspaper website with more than twice the number of unique visitors as the next most popular site. As of May 2009, nytimes.com produced 22 of the 50 most popular newspaper blogs. NYTimes.com is ranked 118 in the world and 32 in the U.S. by Alexa (as of June 4, 2017) (The New York Times Company, 2017). 
When we interrogated further information from Usher (2017), and Kaye and Quinn (2010), it was obvious that The NYT has undergone many changes to address the decline in the industry. For example,

The New York Times was made available on the iPhone and iPod Touch in 2008, and on the iPad mobile devices in 2010. It was also the first newspaper to offer a video game as part of its editorial content. In 2010, The New York Times editors collaborated with students and faculty from New York University's Studio 20 Journalism Masters program to launch and produce "The Local East Village", a Hyperlocal blog designed to offer news "by, for and about the residents of the East Village". In 2012, The New York Times introduced a Chinese-language news site, cn.nytimes.com, with content created by staff based in Shanghai, Beijing and Hong Kong, though the server was placed outside of China to avoid censorship issues. (The New York Times Company, 2017)

With the free fall experienced in advertising projections and revenue at the peak of the decline in the US, The NYT reverted to a pay wall again in 2011. This pay wall helped the newspaper to rake in several hundred thousand subscriptions and about $\$ 100$ million US Dollars in revenue as of March 2012 (The New York Times Company, 2017). The newspaper also launched a food section, which was supplemented on the web by properties for home cooks and for out-of-home dining. By 2008,

The New York Times created an app for the iPhone and iPod Touch which allowed users to download articles to their mobile device enabling them to read the paper even when they were unable to receive a signal. In April 2010, The New York Times announced it would begin publishing daily content through an iPad app. As of October 2010, The New York Times iPad app is ad-supported and available for free without a paid subscription, but translated into a subscription-based mode in 2011. In 2010, the newspaper also launched an app for Android smartphones, followed later by an app for Windows Phones. (The New York Times Company, 2017)

The NYT also had a free email alert services it offers to its customers but by May 2003, it began charging for this News Tracker Email Alerts (as it was called). The News Tracker Email Alert Services enabled subscribers to list specific topics or keywords that they are interested in and that are likely to appear in news stories. Whenever such keywords appear in NYT story, it sends an email alert to the subscriber at agreed intervals. This service provided some modest revenue for The New York Times until Google launched its own version with Google News and offered the services for free. This made the NYT payment approach unsustainable. Eventually, the NYT had to revert to a free service model.

The New York Times also had a popular segment on its website called CalendarLive which showcases entertainment, culture and lifestyle events. Because this section was very popular with particular visitors as indicated by the traffic at the site, the NYT placed a pay wall on that segment. This brought in additional revenue but also crashed the number of visitors to the site.

The NYT also did a similar thing with its top op-ed columns by putting them behind a pay wall under the banner TimesSelect. This arrangement was regarded as the most watched paid content experiment in the newspaper industry. In two years, the firm made \$10 million US Dollars from subscriptions until it was sabotaged through the blogosphere. The firm later reverted to a free service but began attracting enough advertisements to augment for the revenue lost from the pay wall to free content.

The NYT also laid off staff and continued to slash other operational costs to walk its way back to economic health. This helped but also came with its own challenges like reduction in quality and variety of content available to the loyal consumers.

Nikki Usher, in his seminal work on, Making News at the New York Times published in 2014 and reprinted in 2017 chronicled how the NYT took another progressive step forward with the creation of the Continuous 
News Desk (CND) in 1999, "an effort to bring together the print and web newsrooms". CND's function was to update content for the web with wires and some original reporting, while other reporters worked on the main story for print. This effort culminated in the integration of the print and online newsrooms where print reporters eventually took up the responsibilities of web tasks and others would be principally devoted to the production of the website and its associated activities (Usher, 2017).

The NYT continued in this integration till date by making sure its traditional print reporters saw the benefits of the web and most importantly, its potentials in the 21 st century. We can conclude, from the benefit of our interaction with this firm that the integration between the print and the web worked well at the NYT. This is the major reason why Usher (2017) thinks the NYT is the "undoubtedly the leading online newspaper in the world. It was fifth most popular news site in the world after Yahoo!, MSN, CNN, and the BBC, and saw thirty million unique visitors a month. The NYT had one of the most nimble, quick, stable, and interactive news site in the world (Usher, 2017, p. 39).

The second newspaper is The Los Angeles Times, which took many proactive steps to address the economics of decline. The newspaper redesigned its content and style as well as many other strategies that are captured below:

The paper's content and design style was overhauled several times in attempts to increase circulation. In 2000, a major change reorganized the news sections (related news was put closer together) and changed the "Local" section to the "California" section with more extensive coverage. Another major change in 2005 saw the Sunday "Opinion" section retitled the Sunday "Current" section, with a radical change in its presentation and featured columnists. There were regular cross-promotions with Tribune-owned television station KTLA to bring evening-news viewers into the Times fold. The paper reported on July 3, 2008, that it planned to cut 250 jobs by Labor Day and reduce the number of published pages by 15 percent. That included about 17 percent of the news staff, as part of the newly private media company's mandate to reduce costs. In January 2009, the Times increased its single copy price from 50 to 75 cents and eliminated the separate California/Metro section, folding it into the front section of the newspaper. The Times also announced seventy job cuts in news and editorial, or a 10 percent cut in payroll. (The Los Angeles Times, 2017)

Further interrogation of published documents already in the public domain shows that, "despite the circulation decline, many in the media industry lauded the newspaper's effort to decrease its reliance on "other-paid" circulation in favor of building its "individually paid" circulation base — which showed a marginal increase in a circulation audit. This distinction reflected the difference between, for example, copies distributed to hotel guests free of charge (other-paid) versus subscriptions and single-copy sales (individually paid)" (The Los Angeles Times, 2017).

The third newspaper we studied is the Chicago Tribune. Like the other media firms we studied and analyzed, the Chicago Tribune also downsized through layoffs and buyouts. In fact, the layoffs and buyouts in the Chicago Tribune were unprecedented and worst compared to the other newspaper firms under investigation. The two business executives interviewed also confirmed the firm has lay-off many employees with the most recent happening in 2017. They also stated that the lay-offs did very little to change the fortunes of the company leading to the further cover price increases.

These strategies worked for sometimes for the media firms until something else crops up in the industry to erode its viability. This is the major reason most of the strategies had short life spans in the organizations. However, these setbacks did not deter the print media firms from continuing to evolve strategies to address their economic challenges. These efforts led to the following strategies that have been commonly adopted, applied, or ongoing with various degrees of success in the organizations. They include: 
First is a concerted effort being put together to get Aggregators like Google to pay for the right to provide a news link service with links to news media websites. The idea that is driving this concern is simple. Google for example does not provide news content online but could lead its customers to where the news is. For this linking services it provides, Google gets a lot of traffic on its sites and with lots of traffic comes in advertising revenue. The logic is that advertisers who pay Google are only interested in the visitors who come to Google not necessarily where they go after. But the fact is that Google is selling what it does not produce. Most news visitors to Google are not really interested in Google but merely using it as a gateway to their various news sites or news contents. This attitude makes Google a heavy traffic site and so attracts advertising revenue.

It therefore makes sense to ask Google to pay as an Aggregator, not as a news provider. Google has fought back claiming its activities are legal under "Fair Use" and has refused to pay. All the newspapers support this strategy but none has taken drastic steps to force Aggregators like Google to pay. In essence, Aggregation has not started bringing in the needed extra revenue but the efforts are ongoing. The Nigerian print media industry should also begin to think in this line and join the conversation and be more practical on how it can raise revenue from those who send potential readers to its online news sites.

The second strategy is the optimization of search engines to drive traffic to a firm's website. It is called Search Engine Optimization (SEO). SEO is a key survival strategy for the news media industry. This strategy is put in place to make sure news aggregators, search engines, bloggers and anyone else who can redirect traffic to ones news website are able to scroll the news headlines of these news organizations. In other words, the news firms package their news stories in a way the news aggregators/search engines could locate them and thus redirect traffic to the news firms. In the industry, traffic equals page views and the more page views the news site gets, the more advertisers are interested in advertising on such heavy traffic sites. This consequently leads to more revenue for the news media firms.

It is, however, ironic that the same news aggregators the news media firms complain about that they are reaping where they did not sow are the same aggregators they want to pick up their stories so they can increase the traffic on their sites. This explains why the thorny relationship between the news media firms and the news aggregators is a complicated one.

What is important for the Nigerian media industry is to see Search Engine Optimization as one of the many revenue streams that the industry could exploit to its advantage; the complicated relationship between the news firms and the news aggregators notwithstanding.

The third strategy some of the media organizations have applied to stay afloat is to engage in Hyperlocal coverage. Hyperlocal coverage is a type of coverage that gives a particular community or locality depth so that the members of the community will be interested in the newspaper because of the interest the newspaper has for them and their affairs. Hyperlocal, from an editorial point of view, means:

News reporting that more closely reflects the everyday lives of residents in a particular community - things like opening of a new grocery store, a minor car crash or kids' football league results. Hyperlocal news coverage has become fertile territory for citizen journalist projects, with sites popping up by the hundreds. (Kaye \& Quinn, 2010, p. 44)

Hyperlocal coverage obviously attracts news sources of funding to the media firm no matter how small. What the firms did to take full advantage was to ignite the interest of the community that was hitherto rarely in the news and made them the news. This brought in new readers and secondly, small businesses and firms within the locality that could not advertise in the mainstream media because of cost and reach, now found an 
outlet to reach their target customers in the community where they operate. In other words, the media firms did not just offer the target communities an opportunity to read stories about their communities in the mainstream media, they also offered low-cost advertising space to small businesses and individuals within these target communities to reach their target customers through the media.

Literature analyzed and interviews conducted show that Hyperlocal news coverage was a huge success in encouraging local or community journalism. However, it had mixed commercial success. New streams of revenue came in through this strategy via the new readers and small business advertisers that were encouraged to advertise. But with time, it became creatively difficult to continue to satisfy these "local readers" as we prefer to call them, leading to dwindling interests and readership.

The Nigerian print media industry can take full advantage of Hyperlocal coverage to leverage many of the rural areas or communities not reached by the mainstream media. As a nation, Nigeria is made up of more than 300 ethnic groups or nationalities, each with its linguistic and cultural differences. The media firms could take advantage of this huge heterogeneity to target specific localities or communities instead of continuing with the over centralization that the Nigerian media industry is well known for.

The next strategy adopted by the US print media firms is the reinvention of the Classified Advertisements that were the media's main source of revenue until the economic recession set in. The media firms are now innovatively attracting classified advertisements since the pursuit of mainstream advertisements is no longer forthcoming. The media firms have therefore shifted focus based on the reality that mainstream adverts are no longer available as before because advertisers are cutting down on advertising budgets without looking back. In such a scenario, the media firms have gone back to attract classifieds by innovatively connecting buyers to sellers, job seekers to job vacancies etc and making the small resources from such connection count.

In Nigeria, the classified is still popular. However, the newspapers should make it more attractive in terms of cost, versatility and even personalize it to consumers' specific needs. This will help the Nigerian newspapers maximize the revenue from classified advertisements.

Another vital strategy used by the American newspapers to address the decline in their firms is the microfunding of specific journalistic pieces or productions. The microfunding strategy is usually structured around crowd-funding which is a strategy of getting many interested persons to contribute very little to support a cause, this time, a journalistic project. In the use of crowd-funding, a media firm could gather small contributions from a large number of small investors or those who simply want a particular brand of journalism to remain. The media firm uses such contributions to execute a particular journalistic project, sell the project and return the contributions or use the proceeds to execute another project, if so specified.

Kaye and Quinn (2010, p. 65) explain Crowd-funding better thus:

The financial model takes its name from crowd-sourcing: a way to use a large public via the Internet, as an information resource. Many enterprises have used crowd-sourcing for research and development to design T-shirts, or simply stock photographs or write software. With crowd-sourcing, the people supply the content and expertise. With crowd-funding they supply the cash.

Micro or Crowd-funding is not very popular in Nigeria but could be popularized by Nigerian newspapers if the intentions are noble. There are small investors who would love to get involved in supporting the newspapers if they are rightly approached with a good project. This is the area the Nigerian newspapers need to work on. 
The next strategy we found in place in the US press that could work for the Nigerian print media is to have the mainstream media collaborate with citizen journalists who are looking for credible platforms to disseminate their stories. This strategy presupposes that the mainstream media gives the citizen amateur journalist or individual the platform to publish their stories after the usual editorial treatment. In essence, the citizen journalists go out to gather stories and share same with the mainstream media for free. The (citizen journalists) only benefits by having his/her byline on the story while the mainstream media benefits by having pro-bono reporters do reportorial jobs they would have employed full time reporters or journalists to do.

By applying this strategy, the media firms reduced the overhead costs by reducing the number of journalists or reporters employed full time. The Nigerian print media firms should certainly make use of this strategy. The firms could become even creative with it by paying the citizen journalists stipends for transportation instead of the full salaries and operational costs they would have incurred using full time journalists.

Further interrogation of literature supplied by the US print firms investigated shows the use of Niche and Passion content as credible platforms for building revenue for their newspapers. Kaye and Quinn (2010, p. 101) describe this strategy thus "Niche content is narrowly-focused, deep and highly targeted." The authors continued by stating that "broad and popular content should be offered free to build online traffic" but hard-to-find Niche materials should be offered to specific groups or audiences who place value on such content and are therefore willing to pay for such content. This is what is described as Passion Publishing.

This strategy leads to content segmentation according to peculiar target audiences. The media through this strategy can now prepare general content for the general public for free and then go the extra mile to get specific valued content for specific audience who are willing to pay. This could help balance the equation between delivery of free content and paid content online. We also think the Nigerian newspapers can toe the same line to build both traffic and revenue in the news websites. In essence, having an efficient and effective news website by the Nigerian newspapers is no longer an option. That is the way to go to pursue after advertisers who are placing all their ads on online platforms with proven traffic of customers the advertisers are actually interested in.

As we begin to conclude, what these strategies point to for the Nigerian press that is undergoing similar economics of decline is that the media industry in Nigeria should become more innovative in addressing the economic decline. One of the major ways is to merge the print newsroom and the web newsroom. In this case, print reporters must learn to become online news reporters too. This versatility will save their jobs as well as save the industry from the total collapse that may engulf it before 2030 .

\section{Conclusion: Vision 2030 for the Nigerian Print Media Industry}

The future of the Nigerian newspaper industry is not guaranteed beyond 2030. Our findings in the two previous background studies (See Oyokunyi et al., 2017; Batta et al., 2017) provide us with the facts to so predict. However, there is a way out. This solution is what we have tagged in this paper as the "Vision 2030 for the Nigerian Print Media Industry". The components of this Vision are an understanding and application of the following strategies to address the decline in the next decade or face imminent extinction. Based on this, we make these recommendations as part of the Vision 2030 to save the Nigerian print media industry:

First, the industry should begin the process of migration to the "Free Print Newspaper (FPN)". This is no longer avoidable. The Nigerian newspapers should begin to think along this line or lose out entirely to online 
news sites. With the free print newspaper, newspaper firms can begin to push for more distribution of more copies to more places. In other words, the focus should now be on how many copies the newspaper is able to distribute or how many readers it has. With a solid readership base, facilitated by the free copies, the newspaper can begin to attract the advertisers that have migrated online. The logic in this argument is based on the fact that advertisers would be attracted by huge readership base especially those they consider as target consumers/customers. Show them evidence that you have one million readers every day and they get your attention and return all the missing ads.

Second, the same "free" principle for the printed newspaper must be applied for the online version. In essence, we are advocating free news sites. This will help build traffic to the sites and eventually attract advertisers who are ever willing to pay whenever they are convinced of the number and type of visitors to a particular news site. This has worked in the West. It can work for the Nigerian newspapers as they fully migrate online.

However, the print firms could maintain some special services for those who want and can pay. For example, you can send special news reports to individual emails or SMS to them as long as they are willing to pay. Users can also subscribe to receive texts about their favorite sports teams, fashion news, celebrity gossip, etc. A substantial amount of revenue could be generated through this service because in every society, especially in Nigeria, there are individuals who love to be given preferential treatment and would feel obliged to pay in return. Exploit such vanities to the firm's advantage.

A critical aspect of our Vision 2030 for the Nigerian Print Media Industry is the restructuring of the newsroom to make it smarter with smarter and versatile work force that can multi-task. This may not sound good to many in the industry but most firms in the industry need to reduce or rationalize staff, whichever sound better and merge the print newsroom with the digital newsroom and only keep those staff that can multi-task at both platforms. Big workplace and workforce are no longer fashionable in this age of economic decline.

Having studied some of the factors that caused economic recession in the print media industry all over the world, we think the era of "Very Big" print media firms is disappearing. Big print newspaper firms will no longer be fashionable. Start small and grow to medium and manageable size. They should never get to the level where salaries, allowances and maintenance of company infrastructure are as big as the cost of content generation and production.

As part of the industry restructuring and staff rationalization, the newspaper firms must maintain a very lean Management staff that must have actual portfolios that deliver on the core expectations of the firm's line of business. This also directly leads to the firms maintaining compact structures and fix assets that are not flamboyant or meant to show off the "we have arrived or we have made it" mentality.

The industry may also have to join forces with other firms in the industry to experiment on an online police and start suing any blogger or user who uses the firm's content without permission or violates the "Fair Use" doctrine. This is not against the free model we have earlier proposed but meant to check bloggers who take advantage of the free content online to make money for themselves and at the same time allow the content providers to hang out dry.

The media firms in the Nigerian print media industry must strive to build a community of customers and make them loyal if not dependent on the firm for their specific information needs. They should stop trying to have a wide and massive readership base of all kinds of people. In other words, they should not try to be 
attractive to ALL. They should have specific target audience to reach out to and build them to a community. If they take care of readers; readers will take care of them.

The industry stakeholders should provide a support fund to encourage curriculum review that would lead to the emergence of "Media Entrepreneurship" as a course in the new curriculum of most media training institutions in Nigeria. They should also be willing to make themselves available as adjunct staff to practically deliver the content of the new course. This will the industry recruit personnel who are coming in to contribute not just as reporters and correspondents but as experts in the business aspect of media production.

In conclusion, whatever happens, the industry stakeholders should let transparency, credibility, and professionalism remain critical news values that continue to drive the industry. When these triple journalism values are compromised for any reason especially economic, the industry will die a natural death.

\section{References}

Barthelemy, S., Bethell, M., Christiansen, T., Jarsvall, A., \& Koinis, K. (2011). The future of print media. Capstone Report. Columbia University/World Newsmedia Research Group.

Batta, H., Ekeanyanwu, N. T., \& Batta, N. W. (2017). Decline and survival strategies of the newspaper industry in a depressed economy: A study of the Daily Trust and the Leadership newspapers. The Nigerian Journal of Communication, 14(1), 281-320.

Brandwork Nigeria. (2009). Advertisers body releases print circulation survey report. Retrieved November 11, 2013, from https://www.brandworknigeria.com

Collins, R. (2013). Newsonomics of the future: Death of the newspaper industry - New bad things. Retrieved April 5, 2017, from https://www.theeuropean-magazine.com/richardcollins

Curran, J. (2010). The future of journalism. Journalism Studies, 11(4), 464-476.

Dear, J. (2009). The media are failing democracy: Politicians are failing the media. Retrieved December 2, 2013, from http://www.cpbf.org.uk/index_conf.html

Ekeanyanwu, N. T. (2013). Media freedom, political conflicts and the Nigerian cultural dialectics: The American example. In P. Umaru, N. Chinenye, \& I. Nsikak (Eds.), Politics, Culture and the Media in Nigeria (pp. 139-155). Ibadan: Stirling Horden Publishers.

Gill, P., Stewart, R., Treasure, E., \& Chadwick, B. (2008). Methods of data collection in qualitative research: Interviews and focus groups. British Dental Journal, 204(6), 291-295.

Jamshed, S. (2014). Qualitative research method - Interviewing and observation. Journal of Basic and Clinical Pharmacy, 5(4), $87-88$.

Kaye, J., \& Quinn, S. (2010). Funding journalism in the digital age: Business models, strategies, issues and trends. New York: Peter Lang Publishing.

Kurpius, D. D., Metzgar, E. T., \& Rowley, K. M. (2010). Sustaining hyperlocal media: In search of funding models. Journalism Studies, 11(3), 359-379.

Lavrusik, V. (2009). 12 things newspapers should do to survive. Retrieved April 5, 2017, from https://Lavrusik.com

Maja-Pearce, A. (1995). African media directory. Brussels: International Federation of Journalists.

Media Entertainment and Arts Alliance (MEAA). (2008). Life in the clickstream: The future of journalism. Redfern, NSW: MEAA.

Meyer, P. (2004). The vanishing newspaper. Columbia: University of Missouri.

Oyokunyi, J. I., Ekeanyanwu, N. T., \& Aniebo, S. (2017). Economics of decline and survival strategies of Nigerian print media industry: A study of The Guardian; The Sun and Leadership Newspapers. University of Uyo Journal of Humanities, 21(2), 305-327.

Project for Excellence in Journalism. (2008). Financial woes overshadow all other concerns for journalists. Retrieved December 2 , 2013, from http://www.pewtrusts.org/our_work_report_detail.aspx?id=36600

Project for Excellence in Journalism. (2009). The state of the news media 2009: An annual report on American journalism. Retrieved December 2, 2013, from http://www.stateofthenewsmedia.org/2009/

Saperstein, T. (2014). The future of print: Newspapers struggle to survive in the age of technology. Harvard Political Review, December 6. 
The Economics. (2006). "More media, less news". The Economics.

The Los Angeles Times. (2017). The Los Angeles Times. Retrieved August 8, 2017, from http://www.latimes.com/la-mediagroup-times-history-htmlstory.html

The New York Times Company. (2017). The New York Times Company. Retrieved August 8, 2017, from https://www.nytco.com/ Ugboajah, F. (1980). Communication policies in Nigeria. Paris: UNESCO.

Ukonu, M., Ani, M., \& Ndubisi, C. (2013). The influence of online newspaper readership on print newspaper purchases: A study of Nigerian universities in the south-east. The Nigerian Journal of Communication, 11(1), 190-213.

Usher, N. (2017). Making News at The New York Times. Michigan, USA: University of Michigan Press.

Wendt, L. (1979). Chicago Tribune: The Rise of a Great American Newspaper. Chicago: Rand McNally.

World Association of Newspapers (WAN). (2008). World press trends: Newspapers are a growth business. Media Release, Goteburg, 2 June.

Young, S. (2010). The journalism crisis: Is Australia immune or just ahead of its time? Journalism Studies, 11(4), 610-624. 